\title{
Enterprise's Finances: Possible Customer's Risks when Outsourcing Accounting
}

\author{
Marina Evgenievna Ordynskaya, ${ }^{1, *}$, Ruslan Aslancherievich Tkhagapso ${ }^{2}$, \\ Irina Grigorevna Tkharkakhova ${ }^{1}$, Dana Izmailovna Ponokova ${ }^{1}$ \\ ${ }^{1}$ Adyghe State University, 208 Pervomayskaya Street, Maykop, 385000, Russian Federation \\ ${ }^{2}$ Kuban State University, 149 Stavropolskaya Street, Krasnodar, 350040, Russian Federation
}

Received March 20, 2021; Revised May 28, 2021; Accepted June 19, 2021

\section{Cite This Paper in the following Citation Styles}

(a): [1] Marina Evgenievna Ordynskaya, Ruslan Aslancherievich Tkhagapso, Irina Grigorevna Tkharkakhova, Dana Izmailovna Ponokova, "Enterprise's Finances: Possible Customer's Risks when Outsourcing Accounting," Universal Journal of Accounting and Finance, Vol. 9, No. 3, pp. 424 - 430, 2021. DOI: 10.13189/ujaf.2021.090317.

(b): Marina Evgenievna Ordynskaya, Ruslan Aslancherievich Tkhagapso, Irina Grigorevna Tkharkakhova, Dana Izmailovna Ponokova (2021). Enterprise's Finances: Possible Customer's Risks when Outsourcing Accounting. Universal Journal of Accounting and Finance, 9(3), 424 - 430. DOI: 10.13189/ujaf.2021.090317.

Copyright $\odot 2021$ by authors, all rights reserved. Authors agree that this article remains permanently open access under the terms of the Creative Commons Attribution License 4.0 International License

\begin{abstract}
The study aims to determine the essence, classification, reduction methods, and the impact on accounting organization of the risks faced by the customer and the contractor when outsourcing accounting. The article examines the types of risks that arise when outsourcing accounting. Based on the use of such scientific methods as logical generalization and comparison, as well as an expert survey, the following classification criteria and types of risks for the customer have been identified: concerning the customer's activities (operational, financial, control); by the level of loss and distortion of information (risk of disclosure of confidential information, risk of loss of customer documentation, accounting risk); by the aspect of emergence (psychological, moral, loss of reputation); by the source of occurrence (subjective, objective), by the possibility of prediction (predicted, unpredictable); by the possible consequences (risk resulting in loss to the customer; risk resulting in the customer receiving a specified level of income). The reasons and consequences of the proposed types of risks have been determined. The authors also have determined the influence of each of them on accounting organization and the main stages of risk management and methods of risk reduction. The practical importance of improving the classification of risks in outsourcing accounting is to assist parties in contractual relations in developing a strategy and forecasting business activities. The theoretical value lies in the possibility of using the research results to develop new classifications.
\end{abstract}

Keywords Risk Classification, Types of Risks, External Specialist, Customer Enterprise, Methods of Risk Reduction

\section{Introduction}

Development and existence of a socio-economic system are closely intertwined with the constant correlation of certainty and uncertainty of economic conditions, conservatism, and innovation in the activity of economic entities [1,2]. Changes in business conditions, transformation processes in the state, the growing role of accounting information for making managerial decisions, alternative accounting, and the need to determine ways to comply with professional ethics and its impact on accountants' responsibility contribute to the emergence of a situation of uncertainty. This, in turn, creates risk and the need to determine how to reduce it $[3,4]$.

Currently, financial and outsourcing accounting is becoming more popular in world practice. Thus, according to the Annual Report on Financial and Outsourcing accounting-2018, prepared by the research company Everest Group, the global market for outsourcing in the field of finance and accounting in 2017 showed steady growth from 8 to $10 \%$, reaching an annual volume of 6.4 billion US dollars. This shows how 
confident businesses and firms are in the sustainability of this industry [5].

The Client Accounting Services (CAS) Survey 2018, conducted by Bill.com and CPA.com, surveyed 1,700 small and medium-sized firms (SMEs) and found that companies that outsourced their accounting services reported an increase in profits $(28 \%)$ and revenue $(23 \%)$. $80 \%$ of CAS customers said they had more time to focus on their business. $68 \%$ of companies that outsourced accounting reported that accounting had become easier and more efficient. Approximately $30 \%$ of companies that outsourced accounting received advice from their accounting firms, which helped them increase profits. The same percentage also felt more prepared to make business decisions [6].

Russian companies are also increasingly turning over payroll and accounting to professional service providers. According to the largest Russian rating agency RAEX, the accounting outsourcing market grew by $12 \%$ in 2019 [7]. According to the data of the Statista portal [8], in 2019, the leading company in the field of outsourcing accounting in Russia was Sberbank Solutions with an annual turnover of more than 1.6 billion rubles. BDO Unicon Outsourcing, the turnover of which exceeds 1.3 billion rubles, is in the second place. Schneider Group, Unistaff Payroll Company, and RN-Uchet are also among the top ten companies providing accounting services to enterprises in Russia.

Meanwhile, the use of the services of external specialists in accounting on a contractual basis has both positive and negative aspects. The latter, in particular, are associated with the risks of activities, since the accounting process is constantly in the conditions of uncertainty. The emergence of risks in accounting outsourcing and their impact on the final result increase the relevance of their identification, systematization, evaluation, and determination of reduction methods.

The emergence of risks in accounting by external specialists is associated with the existence of a situation of uncertainty, which consists in: a) the presence of options and the need to choose one of them; b) impossibility to foresee the result of the work of external specialists involved; c) the possibility of disclosing commercial secrets; d) the likelihood of loss of material, financial, and labor resources when attracting external specialists, etc. [9].

A significant number of types of risks and criteria for their classification necessitates their study and the selection of those types that arise directly during the outsourcing accounting. Identifying specific types of risks in the selected area of research will help to find and develop appropriate management methods for each of them, which is an urgent task.

\section{Literature Review}

E. Krell [10] identifies the following types of problems (risks) that arise for service customers in accounting by external specialists: management complexity, changes to contracts, quality of services provided, limited transparency, information leakage, lack of cost savings, hidden costs, lack of flexibility, contractor incompatibility. The results of Krell's research indicate that the largest share is occupied by the risks associated with the complexity of management and changes to contracts (56\%). The risk of the complexity of managing a subdivision that does not belong to the enterprise is primarily associated with the lack of control of managers of the customer enterprise over the timeliness and quality of services provided by external specialists.

Even though a significant number of risks are highlighted that arise during accounting outsourcing, to facilitate the determination of their essence and highlight and improve the classification features, we grouped these risks (Table 1).

Table 1. Types of risks arising from accounting outsourcing, investigated by various authors

\begin{tabular}{|c|c|}
\hline Types of risks & Source \\
\hline The risk of losing confidential information & {$[11,12]$} \\
\hline The risk of incurring additional costs & {$[13,14]$} \\
\hline The risk of not getting the desired savings & {$[15,16]$} \\
\hline $\begin{array}{l}\text { The risk of non-fulfillment of contractual relations and } \\
\text { incurring responsibility for mistakes of the contractor }\end{array}$ & {$[17,18]$} \\
\hline The risk of exposure to subjective factors & [19] \\
\hline $\begin{array}{l}\text { The risk of inconsistency between the cost of services and } \\
\text { their quality }\end{array}$ & {$[20,21]$} \\
\hline $\begin{array}{l}\text { The risk of not considering the specifics of the customer's } \\
\text { activities }\end{array}$ & {$[22]$} \\
\hline $\begin{array}{c}\text { The risk of losing intellectual property and control over } \\
\text { resources }\end{array}$ & {$[23]$} \\
\hline $\begin{array}{c}\text { The risk of management complexity and lack of } \\
\text { flexibility }\end{array}$ & {$[24,25]$} \\
\hline
\end{tabular}

Authors pay considerable attention to the definition of various types of risks that arise when outsourcing accounting.

Research hypothesis: when outsourcing accounting, it is necessary to introduce a phased risk management system created based on an improved classification of the customer's risks with the definition of the content, causes, and consequences of the risks.

Research problems:

- to determine the classification features and types of risks that arise for the customer when outsourcing accounting;

- to determine the content, causes, and consequences of risks when outsourcing accounting;

- to characterize the impact of risks on accounting organization and the main stages of risk management.

The article consists of an introduction, literature review, research methodology, results, discussion, and conclusion. 


\section{Methods}

A qualitative study of the possible risks for the customers when transferring accounting to outsourcing was carried out to achieve this goal. Thus, several general and special scientific methods were used. Among them, it is necessary to highlight:

- the methods of logical comparison and generalization in the analysis of the positions of researchers - to determine the types of risks arising from the transfer of accounting to outsourcing;

- the expert survey method - to clarify and concretize according to the classification the features of risks that arise for the customer when outsourcing accounting; to determine the consequences of the customer's risks when outsourcing accounting, the impact of risks on the customer's accounting organization, and the main stages of risk management.

- method of expert assessments - to determine the level of risks; each expert working separately is presented with a list of primary risks based on questionnaires for all stages of the project; it is proposed to assess the likelihood of risks occurring in accordance with the following rating system: $0-$ the risk is considered insignificant; 25 - there is a high probability that the risk is not realized; 50 - nothing definite can be said about the occurrence of the event; 75 - there is a high probability that the risk is realized; 100 - the risk is realized with full confidence.

The main method of research was an expert survey. The main method of research was an expert survey. Experts were asked to voluntarily fill out a semi-formal questionnaire.

Due to the expert survey, the classification features and types of risks that arise for the customer when outsourcing accounting was identified. We also identified the content, causes, and consequences of the customer's risks in outsourcing accounting, the impact of risks on the organization of the customer's accounting, and the main stages of risk management.

\section{Procedure, research tools}

The survey was attended by experts in the field of accounting (44 people). The experts included people whose professional activities had been related to accounting for more than 10 years with sufficient experience and knowledge in the field of accounting to formulate conclusions and practical recommendations.
All participants were warned about the purpose of the survey and the planning by the study organizers to publish results in a generalized form.

When using the method of expert assessments, expert assessments were subject to a consistency analysis, which was carried out according to certain rules:

1. The maximum allowable difference between the assessments of two experts on any factor should not exceed 50. Comparisons are made by module (plus or minus signs are not considered). This makes it possible to eliminate unacceptable differences in expert assessments of the likelihood of an individual risk occurring. If the number of experts is three or more, then pairwise comparative opinions are evaluated.

2. When assessing the consistency of expert opinions on the entire set of risks, the maximum pairwise divergence of expert opinions (minimum commonality) is considered. To calculate the discrepancy, the estimates are summed up by module and the result is divided by the number of risks. The fraction of the division should not exceed 25 .

3. If contradictions are found between the opinions of experts (at least one of the above rules is not met), they are discussed at a meeting with experts. In the absence of contradictions, all expert assessments are reduced to the average (arithmetic mean), which is used in further calculations.

\section{Statistical analysis}

During the mathematical processing of the research results, the percentage of expert references was determined:

- types of risks, depending on their classification features, that arise for the customer when outsourcing accounting;

- the consequences of the occurrence of various types of customer risks when outsourcing accounting;

- the impact of various types of risks on the organization of the customer's accounting.

\section{Results}

Considering the developments of researchers and scholars, as well as the expert survey results, we developed classification features and supplemented the types of risks that arise for the customer when accounting using services of an external specialist (Table 2). 
Table 2. Classification features (CF), types, and characteristics of risks that arise for the customer when outsourcing accounting

\begin{tabular}{|c|c|c|c|c|}
\hline No. & $\mathbf{C F}$ & Risk name & Risk characterization & $\% *$ \\
\hline \multirow{3}{*}{1} & \multirow{3}{*}{$\begin{array}{c}\text { Concerning the } \\
\text { customer's activities }\end{array}$} & Operational risk & $\begin{array}{l}\text { occurs as a result of human, technical, and technological errors in the } \\
\text { current activities of the enterprise }\end{array}$ & $90.9 \%$ \\
\hline & & Financial risk & $\begin{array}{l}\text { risk of additional costs as a result of changes in the pricing policy of an } \\
\text { external specialist and fines as a result of their work }\end{array}$ & $95.5 \%$ \\
\hline & & Control risk & $\begin{array}{l}\text { risk of ineffective organization of the internal control system to detect } \\
\text { errors and irregularities in accounting on a contractual basis }\end{array}$ & $86.4 \%$ \\
\hline \multirow{3}{*}{2} & \multirow{3}{*}{$\begin{array}{c}\text { By the level of loss } \\
\text { and distortion of } \\
\text { information }\end{array}$} & \begin{tabular}{|c|} 
Risk of disclosure of \\
confidential \\
information
\end{tabular} & $\begin{array}{l}\text { risk of losing information that is of value to the customer, which may lead } \\
\text { to negative results in the course of activity }\end{array}$ & $81.8 \%$ \\
\hline & & $\begin{array}{c}\text { Risk of documentation } \\
\text { loss }\end{array}$ & $\begin{array}{l}\text { occurs as a result of not well-organized document exchange system } \\
\text { between the customer and the contractor }\end{array}$ & $72.7 \%$ \\
\hline & & Accounting risk & $\begin{array}{l}\text { probability of misstatement of accounting information and statements as a } \\
\text { result of the use of alternative accounting methods and intentional or } \\
\text { erroneous actions of the contractor }\end{array}$ & $86.4 \%$ \\
\hline \multirow[b]{2}{*}{3} & \multirow{2}{*}{$\begin{array}{c}\text { By the source of } \\
\text { occurrence }\end{array}$} & Subjective risk & risk is related to the activities of the parties to the contractual relationship & $63.6 \%$ \\
\hline & & Objective risk & $\begin{array}{l}\text { risk associated with the influence of external factors that are unregulated on } \\
\text { the accounting process }\end{array}$ & $63.6 \%$ \\
\hline \multirow[t]{2}{*}{4} & \multirow{2}{*}{$\begin{array}{c}\text { By the possibility of } \\
\text { prediction }\end{array}$} & Predictable risk & $\begin{array}{l}\text { risk associated with the cyclical development of the economy and changes } \\
\text { in the stages of market conditions }\end{array}$ & $77.3 \%$ \\
\hline & & Unpredictable risk & risk that arises as a result of the occurrence of force majeure events & $77.3 \%$ \\
\hline
\end{tabular}

Note: compiled based on the expert survey; ${ }^{*}$ - percentage of expert mentions

Table 3. The consequences of the customer's risks when outsourcing accounting

\begin{tabular}{|c|c|c|c|}
\hline No. & Risk name & Consequences & $\% *$ \\
\hline \multirow{4}{*}{1} & \multirow{4}{*}{ Operational risk } & $\begin{array}{l}\text { Destruction, loss of information about the company's activities, reduced efficiency of providing } \\
\text { information, loss of communication channels }\end{array}$ & $90.9 \%$ \\
\hline & & Incorrect organization of accounting, the occurrence of errors in accounting & $95.5 \%$ \\
\hline & & The accrual of penalties & $86.4 \%$ \\
\hline & & Costs related to civil, criminal, and administrative liability & $81.8 \%$ \\
\hline \multirow{2}{*}{2} & \multirow{2}{*}{ Financial risk } & Increased costs for the customer & $72.7 \%$ \\
\hline & & Significant fluctuations in the price and tariffs & $86.4 \%$ \\
\hline \multirow{2}{*}{3} & \multirow{2}{*}{ Control risk } & Incorrect managerial decision making & $63.6 \%$ \\
\hline & & Failure to provide the necessary information to interested users & $63.6 \%$ \\
\hline \multirow{5}{*}{4} & \multirow{5}{*}{$\begin{array}{c}\text { Risk of disclosure of } \\
\text { confidential } \\
\text { information }\end{array}$} & Competitors' use of confidential information & $77.3 \%$ \\
\hline & & The decline in the competitiveness of the enterprise & $81.8 \%$ \\
\hline & & The loss of know-how & $72.7 \%$ \\
\hline & & Incurring financial costs & $86.4 \%$ \\
\hline & & Loss of customers & $72.7 \%$ \\
\hline \multirow{2}{*}{5} & \multirow{2}{*}{\begin{tabular}{|c|}
$\begin{array}{c}\text { Risk of documentation } \\
\text { loss }\end{array}$ \\
\end{tabular}} & Incorrect and non-operational reflection of the results of operations in the financial statements & $77.3 \%$ \\
\hline & & Providing false information & $86.4 \%$ \\
\hline \multirow{3}{*}{6} & \multirow{3}{*}{ Accounting risk } & Making irrational decisions by the customer & $90.9 \%$ \\
\hline & & Loss of confidence in the information reflected in the financial statements & $68.2 \%$ \\
\hline & & Loss of assets & $95.5 \%$ \\
\hline \multirow{2}{*}{7} & \multirow{2}{*}{ Subjective risk } & Failure to obtain the desired result of the activities of both parties to the contract & $86.4 \%$ \\
\hline & & The asymmetry of information contributes to the non-fulfillment of obligations by the contractor & $81.8 \%$ \\
\hline \multirow{2}{*}{8} & \multirow{2}{*}{ Objective risk } & Misrepresentation of credentials & $72.7 \%$ \\
\hline & & Incorrect decision-making by the customer & $68.2 \%$ \\
\hline 9 & Predictable risk & The possibility of "price" blackmail on the part of the contractor & $72.7 \%$ \\
\hline \multirow{2}{*}{10} & \multirow{2}{*}{ Unpredictable risk } & Unforeseen losses of the customer & $81.8 \%$ \\
\hline & & Additional costs for finding a new contractor for accounting services & $68.2 \%$ \\
\hline
\end{tabular}

Note: compiled based on the expert survey; * - percentage of expert mentions

The experts believed that the determination of the consequences of the customer's risks when outsourcing accounting following the proposed classification criteria (Table 3) allows choosing the right and best method of 
managing each of them, developing appropriate documentation.

The expert survey also revealed the need to determine the methods of risk reduction in accounting by an external specialist is also determined by the direct or indirect impact of each of the above-mentioned risks on accounting organization at the customer's enterprise (Table 4).

\section{Discussion}

Table 3 shows that each of the above risks can lead to negative consequences for the customer's enterprise. As a result, the organization of the risk management system becomes an urgent and relevant issue. The main stages of the risk management process are shown in Table 5.

Table 4. The impact of risks on accounting organization of the customer

\begin{tabular}{|c|c|c|c|}
\hline No. & Risk name & Impact on accounting organization & $\% *$ \\
\hline \multirow{2}{*}{1} & \multirow{2}{*}{ Operational risk } & $\begin{array}{l}\text { The need to improve the contractual policy of the customer and internal reporting } \\
\text { indicators that characterize the contractual process in terms of accounting }\end{array}$ & $90.9 \%$ \\
\hline & & $\begin{array}{l}\text { It is necessary to ensure the consistency of the software of the customer and the contractor } \\
\text { in the conditions of using a computerized form of accounting }\end{array}$ & $77.3 \%$ \\
\hline 2 & Financial risk & $\begin{array}{c}\text { In the accounting policy, it is necessary to provide for the order of reflection in the } \\
\text { accounting of possible expenses of the customer in the event of a change in the pricing } \\
\text { policy of the contractor }\end{array}$ & $86.4 \%$ \\
\hline \multirow[t]{2}{*}{3} & \multirow[t]{2}{*}{ Control risk } & $\begin{array}{c}\text { Determining the responsible person (an employee of the customer company) who will } \\
\text { control the process of transmitting and receiving information from the contractor, as well } \\
\text { as the timeliness and completeness of the services provided }\end{array}$ & $81.8 \%$ \\
\hline & & $\begin{array}{c}\begin{array}{c}\text { Development of the job description and consolidation of the corresponding rights, duties, } \\
\text { and forms of responsibility }\end{array} \\
\end{array}$ & $63.6 \%$ \\
\hline \multirow{3}{*}{4} & \multirow{3}{*}{$\begin{array}{l}\text { Risk of disclosure of } \\
\text { confidential information }\end{array}$} & $\begin{array}{c}\text { Organization of continuous monitoring of the implementation of the information security } \\
\text { policy }\end{array}$ & $86.4 \%$ \\
\hline & & Contractual settlement of the liability for disclosure of trade secrets & $72.7 \%$ \\
\hline & & The need to improve administrative information security measures & $63.6 \%$ \\
\hline \multirow{3}{*}{5} & \multirow{3}{*}{ Risk of documentation loss } & $\begin{array}{l}\text { Identification of responsible persons for the creation, verification, processing, transfer, } \\
\text { and storage of documentation at the enterprise and fixing their list in internal } \\
\text { administrative documents }\end{array}$ & $95.5 \%$ \\
\hline & & $\begin{array}{l}\text { Mandatory development and coordination of the document flow schedule between the } \\
\text { customer and the contractor }\end{array}$ & $81.8 \%$ \\
\hline & & determination of the contractor's reporting procedure to the customer & $72.7 \%$ \\
\hline 6 & Accounting risk & $\begin{array}{c}\text { Coordination with the customer of all provisions of the accounting policy, the procedure } \\
\text { for the development of the Order on accounting policy and all necessary annexes to it }\end{array}$ & $86.4 \%$ \\
\hline 7 & Subjective risk & $\begin{array}{l}\text { The contract should provide for the responsibility of external specialists involved in } \\
\text { accounting }\end{array}$ & $72.7 \%$ \\
\hline 8 & Objective risk & \multirow{3}{*}{$\begin{array}{l}\text { When developing the accounting policy of the customer, it is necessary to consider } \\
\text { changes in the external environment and their impact on economic activity }\end{array}$} & \multirow{3}{*}{$77.3 \%$} \\
\hline 9 & Predictable risk & & \\
\hline 10 & Unpredictable risk & & \\
\hline
\end{tabular}

Note: compiled based on the expert survey; ${ }^{*}$ - percentage of expert mentions

Table 5. The main stages of risk management and their characteristics

\begin{tabular}{|c|c|c|c|}
\hline No. & Stage name & Characteristics & Procedure \\
\hline 1 & Risk identification & $\begin{array}{c}\text { Establishing a list of the main } \\
\text { types of risks }\end{array}$ & $\begin{array}{c}\text { The list of systematic risks of the enterprise, which do not depend on } \\
\text { the operation of the enterprise, is determined }\end{array}$ \\
\hline 2 & Qualitative risk assessment & $\begin{array}{c}\text { Grouping of risks by the degree } \\
\text { of their impact on the final } \\
\text { result }\end{array}$ & $\begin{array}{c}\text { The influence of objective and subjective factors on the size of the } \\
\text { identified risks is determined. These types of risks are arranged } \\
\text { according to the degree of their impact on the result of activity }\end{array}$ \\
\hline 3 & Quantitative risk assessment & $\begin{array}{c}\text { Assessment of the probability of } \\
\text { occurrence and consequences of } \\
\text { risk }\end{array}$ & $\begin{array}{c}\text { Statistical, heuristic (expert assessment methods), or analytical } \\
\text { methods are used to estimate the probability of losses and determine } \\
\text { their magnitude }\end{array}$ \\
\hline 4 & $\begin{array}{c}\text { The choice of risk reduction } \\
\text { methods }\end{array}$ & $\begin{array}{c}\text { Identification of methods to } \\
\text { avoid or minimize risk }\end{array}$ & $\begin{array}{c}\text { Risk optimization methods are selected (external: risk allocation, } \\
\text { insurance; internal: limitation, diversification, creating reserves, } \\
\text { obtaining additional information) }\end{array}$ \\
\hline
\end{tabular}

Note: compiled based on the expert survey. 
Table 6. Expert assessment of accounting risks

\begin{tabular}{|c|c|c|c|c|c|c|c|c|c|c|}
\hline \multirow{2}{*}{ Expert } & \multicolumn{2}{|c|}{ Criterion 1 } & \multicolumn{2}{c|}{ Criterion 2 } & \multicolumn{2}{c|}{ Criterion 3 } & \multicolumn{2}{c|}{ Criterion 4 } & \multicolumn{2}{c|}{ Criterion 5 } \\
\cline { 2 - 12 } & significance & rank & significance & rank & significance & rank & significance & rank & significance & rank \\
\hline 1 & 26 & 4 & 43 & 2 & 68 & 1 & 42 & 3 & 20 & 5 \\
\hline 2 & 35 & 3 & 55 & 2 & 59 & 1 & 24 & 5 & 26 & 4 \\
\hline 3 & 41 & 2 & 31 & 4 & 72 & 1 & 35 & 3 & 18 & 5 \\
\hline 4 & 33 & 3 & 44 & 2 & 63 & 1 & 30 & 4 & 24 & 5 \\
\hline 5 & 22 & 4 & 58 & 1 & 57 & 2 & 44 & 3 & 17 & 5 \\
\hline 6 & 34 & 4 & 53 & 2 & 70 & 1 & 41 & 3 & 23 & 5 \\
\hline 7 & 27 & 4 & 60 & 1 & 55 & 2 & 33 & 3 & 19 & 5 \\
\hline 8 & 40 & 2 & 37 & 3 & 75 & 1 & 36 & 4 & 20 & 5 \\
\hline 9 & 25 & 4 & 34 & 2 & 66 & 1 & 31 & 3 & 28 & 5 \\
\hline 10 & 29 & 5 & 42 & 2 & 59 & 1 & 40 & 3 & 33 & 4 \\
\hline Total & 31.2 & 4 & 45.7 & 2 & 64.4 & 1 & 35.6 & 3 & 22.8 & 5 \\
\hline
\end{tabular}

The experts suggested that a qualitative assessment of the identified risks should be considered in the context of calculating the lost profit due to possible mistakes made by the contractor. That is, the identified types of risks are arranged according to the degree of their impact on the final result of the enterprise.

When quantifying the risks that arise in the process of interaction between the customer and the contractor, the surveyed experts considered it appropriate to use the method of expert assessments. According to them, using this method allows excluding options for cooperation with external specialists with a significant level of uncertainty. According to the surveyed experts, to obtain a detailed description of the risks that may arise in the process of providing accounting services, the competent experts developed a list of questions for the survey of implementing companies based on certain criteria. As shown in previous research [26,27], the main of these criteria can be: a) the presence of developed schemes of the process of information exchange between the customer and the contractor; b) the processing, storage, and transmission of documents of the customer; c) experience of accounting at the enterprises of the sector; $d$ ) the existence of a contract of insurance risks of the contractor; e) the level of security by computer technology and software for accounting, etc. According to the survey, each criterion is to be assessed using the method of ranks. In this method, the expert assessment is conducted of the importance of each element on a scale of relative importance in the range $0-1,0-10$, or $0-100$. As shown in research [28], this method allows evaluating not only the priority of a certain criterion but also the degree of its weight. Then these criteria are ranked and the degree of influence of the corresponding type of risk on the result of the customer's activity is determined.

An example of expert assessment of accounting risks by 10 experts according to the given criteria (on a 100-point scale, see Methods) is presented in Table 6 .
Based on the results of the risk assessment, the main methods of their reduction are determined. Following the above classification and the nature of risks, the experts considered it appropriate to use the following methods to reduce them: risk allocation - partial transfer of responsibility for the risk to the contractor, obtaining additional information (if there are inaccuracies); risk transfer - full or partial transfer of responsibility (based on a contract) to reduce risks and neutralize their negative consequences to the contractor or insurance company. Each of the considered risk management methods has its advantages and disadvantages. The use of each of them depends on the type and level of risk.

\section{Conclusion}

The following conclusions can be drawn.

The lack of a unified approach to determining the criteria for risk classification when outsourcing accounting led to the need for scientific justification of the classification of these risks.

The conducted research allows concluding that the effectiveness of a company's accounting system significantly depends on an adequately adopted risk reduction system. The perfection of this system in accounting, which should be developed by the accounting department of each enterprise, largely depends on the choice of risk assessment tools and methods of accounting for them in the current economic activity. In the process of forming such systems, it is necessary to combine the control of the level of risks in accounting with the analysis of the financial results of the enterprise, developing adequate analytical tools.

The prospect of further research may be an analysis of the contractor's risks when outsourcing accounting, as well as the development of a program for managing the risks that arise when outsourcing accounting. 


\section{REFERENCES}

[1] Krasnov, B. Beknazarov, D. Jarikbayeva, D. Yeshpanova, A. Karshalova. Security of the Eurasian economic union member states: socioeconomic and financial aspects, Journal of Security and Sustainability Issues, Vol.9, No.2, 637-648, 2019.

[2] L. I. Shubtsova, E A. Kostromina, O. I. Chelyapina, N. A. Grigorieva, P. V. Trifonov. Supporting the Tourism Industry in the Context of the Coronavirus Pandemic and Economic Crisis: Social Tourism and Public-Private Partnership, Journal of Environmental Management and Tourism, Vol.11, No.6, 1427-1434, 2020.

[3] Krasnov, A. Okanova, Y. Yeraliyeva, M. Kozhakhmetova, A. Karshalova, M. Aitkazina. Development of the financial policy of the Eurasian economic union countries: tax harmonization, Entrepreneurship and Sustainability Issues, Vol.8, No.1, 138-149, 2020.

[4] M. M. Milovanova, T. S. Markova, V. A. Mushrub, M. E. Ordynskaya, J. V. Plaksa. Business education: training in the use of blockchain technology for business development, Revista Inclusiones, Vol.7, No.Especial, 408-420, 2020.

[5] J. M. Narvas, "4 Reasons for Finance and Outsourcing accounting in 2019", D\&V Philippines, Mar 28, 2019, https://www.dvphilippines.com/blog/4-reasons-for-financeand-accounting-outsourcing-in-2019

[6] Nearly 80 Percent of Companies That Outsource Accounting Are Likely to Refer Their Accountants, According to New Survey From Bill.com and CPA.com, BusinessWire, July 24, 2018,

https://www.businesswire.com/news/home/2018072400557 1/en/80-Percent-Companies-Outsource-Accounting-ReferAccountants

[7] E. Lozhkova, "Accounting outsourcing market trends in Russia", Schneider Group, https://schneider-group.com/en/ news/accounting-outsourcing-market-trends-in-russia/

[8] D. Elagina, "Leading outsourcing accounting firms in Russia 2019, by turnover", Statista, Sep 9, 2020, https://www.statista.com/statistics/1023133/russia-leadingaccounting-outsourcing-firms-by-turnover

[9] E. M. Amaka, F. Alio. Outsourcing Accounting Functions: Risks and Benefits, International Journal of Academic Management Science Research, Vol.4, No.10, 3-7, 2020.

[10] E. Krell. Finance and outsourcing accounting: making an informed decision, CMA Management, Vol.81, No.7, 38-40, 2007.

[11] D. Lamminmaki. Accounting and the management of outsourcing: An empirical study in the hotel industry, Management Accounting Research, Vol.19, 163-181, 2008.

[12] R. Aron, Y. Liu. Determinants of operational risk in global sourcing of financial services: Evidence from field research, Brookings Trade Forum, Vol.1, 373-398, 2005.

[13] Aman. Managing Relational Risks in Outsourcing accounting: Experiences of Small Firm, World Applied Sciences Journal, Vol.15, No.1, 56-62, 2011.

[14] R. V. Desai. Finance And Outsourcing accounting: Three
Studies Related To The Ethical And Economic Dimensions Of Outsourcing accounting, Electronic Theses and Dissertations, 2004-2019, 3138, 2007, https://stars.library.ucf.edu/etd/3138.

[15] J. Bierstaker, L. Chen, M. H. Christ, M. Ege, N. Mintchik. Obtaining assurance for financial statements audits and control audits when aspects of the financial reporting process are outsourced, Auditing: A Journal of Practice \& Theory, Vol.32, 209-250, 2013.

[16] S. Espenlaub, B. Nicholson, J. Jones. Transaction costs and control of outsourced accounting: case evidence from Britain and India, Management and Accounting Research, Vol.17, No.3, 238-258, 2006.

[17] K. Van Peursem, L. Jiang. Internal audit outsourcing practice and rationales: SME evidence from New Zealand, Asian Review of Accounting, Vol.16, No.30, 219-245, 2008.

[18] P. Everaert, G. Sarens, J. Rommel. Sourcing strategy of Belgian SMEs: Empirical evidence for the accounting services, Production Planning \& Control, Vol.18, No.8, 716-725, 2007.

[19] K. M. Gilley, A. Rasheed. Making more by doing less: An analysis of outsourcing and its effects on firm performance, Journal of Management, Vol.26, No.4, 763-790, 2000.

[20] H. Höglund, D. Sundvik. Financial reporting quality and accounting outsourcing tasks: Evidence from small private firms, Advances in accounting, Vol.35, 125-134, 2016.

[21] Hafeez, O. Andersen. Factors Influencing Outsourcing accounting Practices among SMEs in Pakistan Context: Transaction Cost Economics (TCE) and Resource-Based Views (RBV) Prospective, International Journal of Business and Management, Vol.9, No.7, 19-32, 2014.

[22] Y. Kamyabi, S. Devi. Accounting outsourcing functions in the context of SMEs in emerging economies: Transaction cost economics perspective, Australian Journal of Basic and Applied Sciences, Vol.5, No.11, 1696-1703, 2011.

[23] J. Jayabalan, M. Raman, M. Dorasamy, N. K. C. Ching. Accounting outsourcing Functions amongst SME Companies in Malaysia: An Exploratory Study, Accountancy Business and the Public Interest, Vol.8, No.2, 96-114, 2009.

[24] R. Reddy. Outsourcing of finance and accounting operations: the feasibility of the vertical in the Indian context, ICFAI Journal of Service Marketing, Vol.6, 23-39, 2008.

[25] M. Elharidy, B. Nicholson, R. Scapens. The embeddedness of outsourcing accounting relationships, Qualitative Research in Accounting \& Management, Vol.10, No.1, 60-77, 2013.

[26] P. Everaert, G. Sarens, J. Rommel. Using Transaction Cost Economics to explain accounting outsourcing, Small Business Economics, Vol.35, No.1, 93-112, 2010.

[27] M. Kotabe, M. J. Mol. Outsourcing and financial performance: A negative curvilinear effect, Journal of Purchasing and Supply Management, Vol.15, 205-213, 2009.

[28] L. A. Platz, A. Temponi. Defining the most desirable outsourcing contract between customer and vendor, Management Decision, Vol.45, No.10, 1656-1666, 2007. 